\title{
Absorption and mobility of radio-labelled calcium in chili pepper plants and sweet cherry
}

\section{trees}

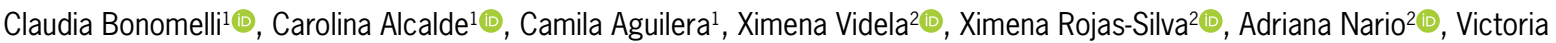 \\ Fernandez ${ }^{3 *}$ (1)
}

'Pontificia Universidad Católica de Chile/Facultad de Agronomía e Ingeniería Forestal, Av. Vicuña Mackenna, 4860 - 7820436 - Macul, Santiago - Chile.

${ }^{2}$ Comisión Chilena de Energía Nuclear/División Investigación y Desarrollo, Nueva Bilbao 12501 - 7600713 - Las Condes, Santiago - Chile.

3Universidad Politécnica de Madrid/ E.T.S.I. de Monte

Forestal y del Medio Natural - Forest Genetics and

Ecophyiosolgy Research Group, C/ José Antonio Novais 10, 28040 Madrid - Spain.

*Corresponding author <v.fernandez@upm.es>

Edited by: Anoop Kumar Srivastava

Received April 06, 2020

Accepted June 23, 2020
ABSTRACT: Calcium (Ca) is often supplied to crop species to prevent the occurrence of Ca-related disorders. Mechanisms of $\mathrm{Ca}$ absorption and transport are not fully understood and the effectiveness of root and/or foliar Ca fertilization may be variable. To characterize the rate of $\mathrm{Ca}$ absorption and transport, trials were developed with chili pepper and sweet cherry plants, using ${ }^{45} \mathrm{CaCl}_{2}$ as a tracer. The Ca treatments supplied were: (1) No ${ }^{45} \mathrm{Ca}$ (control); (2) ${ }^{45} \mathrm{Ca}$ soil application; (3) ${ }^{45} \mathrm{Ca}$ supply to basal leaves, and $(4){ }^{45} \mathrm{Ca}$ application to apical leaves. After two months, plants were harvested for biomass and $\mathrm{Ca}$ content determination. The recovery of ${ }^{45} \mathrm{Ca}$ in different plant parts was measured with a liquid scintillation counter and leaf traits were observed by scanning electronic microscopy. In general, the highest ${ }^{45} \mathrm{Ca}$ concentrations were recovered in treated organs, while root applications led to highest ${ }^{45} \mathrm{Ca}$ translocation rates, which varied between chili pepper and cherry plants. For chili pepper, ${ }^{45} \mathrm{Ca}$ applied to the soil was detected mainly in roots (44 \%) followed by leaves (36.6 \%) stems $(17.4 \%)$ and fruits (2\%). In sweet cherry trees, soil-applied ${ }^{45} \mathrm{Ca}$ was principally recovered in roots (45.3\%), shoots (28.5\%), leaves (14.3\%) and trunks (11.9\%). The results provide evidence of increased absorption of root-applied $\mathrm{Ca}$, as well as different degrees of $\mathrm{Ca}$ mobility between species. Foliar application led to major $\mathrm{Ca}$ increases in treated leaves, with $\mathrm{Ca}$ transported to other plant organs after apical leaf Ca supply chiefly in cherry trees.

Keywords: fertilizers, fertilizer application methods, horticultural crops, plant nutrition, radioisotopes

\section{Introduction}

Calcium is an essential plant nutrient mainly for cell wall formation, cellular signalling responses, and cell membrane stability (Marschner, 2012). However, Ca ion $\left(\mathrm{Ca}^{2+}\right)$, along with organic acids (e.g., in vacuoles), can form strong precipitates, limiting Ca mobility (de Freitas et al., 2015). Calcium is relatively phloem immobile and thus contribution of phloem transport may be limited (Montanaro et al., 2014; Song et al., 2018). Calcium absorbed from the soil solution is transported from the roots via xylem to different tissues and organs (Khalaj et al., 2016; Saure, 2005). However, root $\mathrm{Ca}^{2+}$ uptake decreases with increasing distance from the root apex (Marschner, 2012) and it is much higher in apical than in basal root zones (Saure, 2005). Transport of Ca to aerial plant organs depends on several factors, such as xylem sap $\mathrm{Ca}^{2+}$ concentration, balanced mineral nutrition, water uptake and plant water potential, transpiration and growth rate (Hocking et al., 2016; Souri and Hatamian, 2019). Excessive Ca accumulation may occur in organs with high transpiration rates (i.e., leaves; de Freitas and Mitcham, 2012; de Freitas et al., 2015), while low transpiring organs may suffer localized $\mathrm{Ca}$ deficiencies, as reported for several fruit and vegetable crops (e.g., Sampaio et al., 1999; Val et al., 2008; Marschner, 2012).

Nowadays, foliar fertilizers are widely used as complementary treatments to root fertilization (e.g., Souri and Sooraki, 2019) and for supplying elements with limited plant mobility, such as Ca or micronutrients
(Gomes et al., 2020; Fernández and Brown, 2013; Torres et al., 2017). When $\mathrm{Ca}$ is applied to the roots, it is first absorbed and then transported in the xylem before distribution following the transpiration stream (Busse and Palta, 2006; White and Broadley, 2003). In the case of foliar $\mathrm{Ca}$ application, the absorption rate is determined by many environmental, physiological, and physicochemical factors, which are currently not fully understood (Fernández and Eichert, 2009; Fernández et al., 2013). The contribution of stomata to the foliar uptake process can be high (Eichert and Burkhardt, 2001; Eichert et al., 2008), but absorption may also occur through the cuticle, cuticular irregularities, trichomes and veins (Bahamonde et al., 2018; Fernández and Bahamonde, 2020). The application of root and foliar $\mathrm{Ca}$ fertilizers is currently recommended to improve plant Ca status, both in herbaceous and woody crops; nevertheless, information on how much of the exogenous $\mathrm{Ca}$ may be transported outside from the treated organs is still unknown. This study investigated the $\mathrm{Ca}$ partitioning and rate of absorption and mobility of ${ }^{45} \mathrm{Ca}$ supplied to chili pepper (herbaceous) and sweet cherry (woody) plants, after root and foliar application.

\section{Materials and Methods}

\section{Plant material, experimental design and $\mathrm{Ca}$ treatments}

Trials were carried out with chili pepper seedlings (Capsicum annuum L.) and two-year-old non-bearing 
sweet cherry (Prunus avium L.) trees grown at the facilities of Pontificia Universidad Católica de Chile, Santiago $\left(33^{\circ} 29^{\prime} \mathrm{S}, 70^{\circ} 36^{\prime} \mathrm{W}, 570 \mathrm{~m}\right.$ above sea level). Each container was filled with 2:1:1 peat: perlite: vermiculite as substrate. Chili pepper plants were kept in a growth chamber at $24^{\circ} \mathrm{C}$ (day/night) air temperature and 16:8 h light: dark photoperiod. Sweet cherry trees were kept outdoors. Chili pepper seedlings were planted in $2.8 \mathrm{~L}$ plastic containers in Oct (spring in the southern hemisphere) and cherry trees were transplanted to 40 L plastic containers in Aug (winter end), before bud break. Irrigation frequency and volume were adjusted according to plant water demand. The initial ${ }^{45} \mathrm{CaCl}_{2}(5$ mCi) solution was diluted with $\mathrm{CaCl}_{2}$. Subsequently, the ${ }^{45} \mathrm{CaCl}_{2}$ treatment solution had a concentration of $7.35 \mathrm{~g} \mathrm{~L}^{-1} \mathrm{CaCl}_{2}$ and an activity of $2,187 \mathrm{~Bq} \mathrm{~L}^{-1}$, with no surfactant added. Using a micropipette, the following treatments were applied to the plants on $14^{\text {th }}$ Nov, 2018: (1) No ${ }^{45} \mathrm{Ca}$ application (untreated, control plants), (2) two $\mathrm{mL}$ of ${ }^{45} \mathrm{Ca}$ solution to soil, distributed in four points, (3) foliar application to basal leaves, and (4) foliar application to apical leaves. ${ }^{45} \mathrm{Ca}$ solutions were supplied once during the growing season. Calcium treatments were applied at the pre-flowering developmental stage of pepper plants and on the second peak of vegetative growth of cherry trees. For foliar treatment to apical or basal leaves, $25 \mu \mathrm{L}$ of the ${ }^{45} \mathrm{CaCl}_{2}$ treatment solution (having $7.35 \mathrm{~g} \mathrm{~L}^{-1} \mathrm{CaCl}_{2}$ and $2,187 \mathrm{~Bq} \mathrm{~L}^{-1}$ activity) was applied to seven chili pepper leaves per plant and 20 sweet cherry leaves per tree, respectively. Trials were carried out following a completely randomized design with three replicates for chili pepper and sweet cherry plants.

\section{Plant biomass and Ca concentration partitioning}

In Jan 2019, that is, two months after ${ }^{45} \mathrm{Ca}$ treatment when growth was already arrested, untreated and ${ }^{45} \mathrm{Ca}$-treated chilli pepper plants and cherry trees were harvested. Plant parts were separated for further analysis, grouping together the leaves, stems, fruits and roots of chili pepper, and the leaves, shoots, trunk and roots of sweet cherry trees. For each species and organ, tissue fresh (FW) and dry (DW) weight (tissues were kept in an oven at $65{ }^{\circ} \mathrm{C}$ for $48 \mathrm{~h}$ ) were consequently determined. Calcium concentration was determined after dry tissue ashing at $500{ }^{\circ} \mathrm{C}(4 \mathrm{~h})$, ash dissolution in $2 \mathrm{M}$ (Sadzawka et al., 2007) and Ca determination by inductively coupled plasma-optical emission spectroscopy (ICP-OES; Agilent 720 ES axial - Varian, Australia). For Ca content estimations, Ca concentration of each organ was multiplied by its DW, expressing $\mathrm{Ca}$ partitioning values as a percentage.

\section{Ca transport after ${ }^{45} \mathrm{Ca}$ application}

Two months after ${ }^{45} \mathrm{Ca}$ application, ${ }^{45} \mathrm{Ca}$ activity (Bq) was measured in different plant fractions and in the soil, in the case of root treatments $(0-5 \mathrm{~cm}$ and $5-10 \mathrm{~cm}$ depth) (Videla et al., 2019). Then, the ${ }^{45} \mathrm{Ca}$ recovered was calculated by considering the amount of ${ }^{45} \mathrm{Ca}$ measured in soil and different tissues, depending on the treatment, plant species, and total ${ }^{45} \mathrm{Ca}$ amount applied in each treatment.

\section{Leaf surface topography and anatomy}

The leaf surface features of chili pepper and cherry leaves were analyzed by scanning electronic microscopy (SEM), with focus on veins, stomata, and mesophyll morphology. Images for characterizing stomatal frequency and pore size (length and width) were collected and analyzed using Image-J software.

\section{Statistical analysis}

In general, data were statistically analyzed with SPSS 15.0 software. They were subjected to the analysis of variance (ANOVA) and differences between factors $\left({ }^{45} \mathrm{Ca}\right.$ application methods and species) were found with the Tukey HSD Tests, when F-values were significant $(p<0.05)$. For assessing Biomass and Ca content, data were first transformed to arcsin-sqrt before ANOVA. Results concerning ${ }^{45} \mathrm{Ca}$ detection were transformed to log prior to ANOVA. The number and size of stomata were also compared by ANOVA.

\section{Results}

\section{Plants biomass and tissue Ca partitioning}

The results for organ biomass and Ca partitioning of chili pepper and sweet cherry plants are shown in Figure 1. For chili pepper, the highest biomass related to stems and leaves (accounting for more than $70 \%$ of plant biomass; Figure 1A). Regarding its distribution in chili pepper (Figure 1B), Ca accumulated mainly in leaves $(40 \%)$, followed by roots (approximately $35 \%$ ) and stems (around $25 \%$ ). Fruits had the least biomass and $\mathrm{Ca}$ partitioning rate (Figure $1 \mathrm{~A}$ and $\mathrm{B}$ ), representing the lowest values recorded in different plant parts. Hence, similar to organ biomass, Ca partitioning was also higher in aerial parts of the chilli pepper plant.

In 2-year-old sweet cherry trees (Figure 1C) the trunk had the highest biomass partitioning (approximately $45 \%$ ), followed by shoots (around $23 \%$ ) and roots (approximately $30 \%$ ), while leaves had the lowest biomass $(<5 \%)$ (Figure $1 \mathrm{C}$ ). Cherry tree roots had the highest Ca partitioning (more than $40 \%$ ), while the remaining aerial parts had lower $\mathrm{Ca}$ amounts, which remained within a similar range (Figure 1D). When comparing the results of the two species, no significant differences between aerial (including stems and trunks) and underground organ biomass distribution were observed (from 70 to $74 \%$ for aerial parts and between 26 to $30 \%$ for roots) (Figures $1 \mathrm{~A}$ and $1 \mathrm{C}$ ). There were significant differences regarding Ca partitioning in some organs of pepper versus cherry plants, with leaves having the highest $\mathrm{Ca}$ amounts in chili pepper (Figure $1 \mathrm{~B})$ and roots showing the greatest $\mathrm{Ca}$ accumulation values in cherry trees (Figure 1 D). 

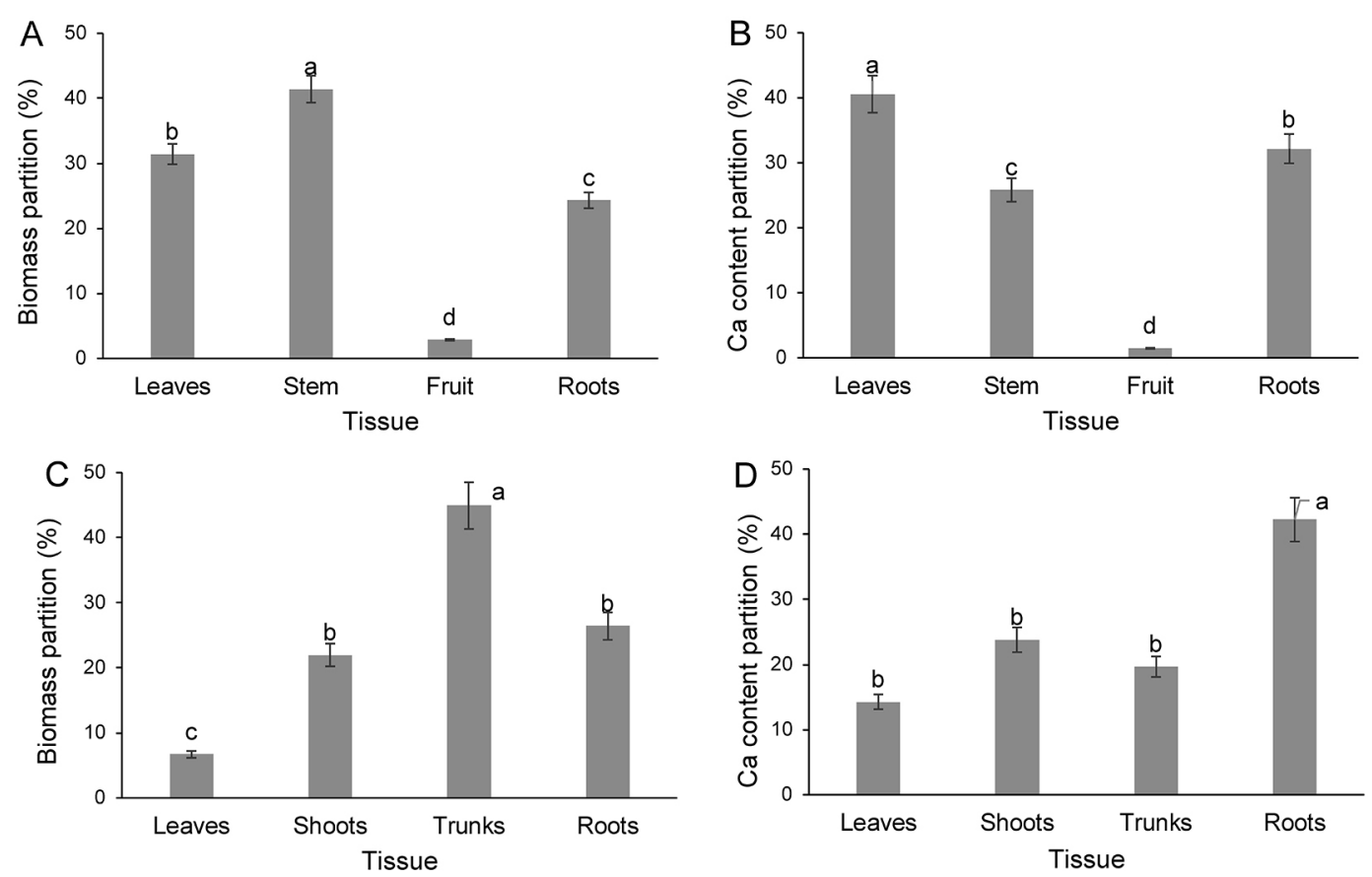

Figure 1 - Chili pepper $(A, B)$ and sweet cherry tree $(C, D)$ biomass partitioning $(A, C)$ and Ca content partitioning $(B, D)$. Data are means \pm standard deviations $(S D, n=3)$. Different letters indicate different levels of significance according to the Tukey test $(p<0.05)$.

\section{Radiolabelled Ca trials}

For both species, the supply of ${ }^{45} \mathrm{Ca}$ via foliar treatment was positively correlated with the concentrations recovered in the treated organs, because the applied ${ }^{45} \mathrm{Ca}$ mostly remained there after leaf application (Figures $2 \mathrm{C}$ to $2 \mathrm{~F}$ ). In the case of root Ca supply, significant differences were found in ${ }^{45} \mathrm{Ca}$ distribution in plant organs. The highest ${ }^{45} \mathrm{Ca}$ recovery values were recorded for treated roots, which were not significantly different between species.

For chili pepper plants, the highest distribution of ${ }^{45} \mathrm{Ca}$ was found after soil treatment with $\mathrm{Ca}$, the highest ${ }^{45} \mathrm{Ca}$ accumulation rate was detected in the roots, followed by leaves and stems (Figure 2A). However, when ${ }^{45} \mathrm{Ca}$ was applied to apical or basal leaves, around $98 \%$ of the supplied ${ }^{45} \mathrm{Ca}$ was recovered in the treated tissues (Figures $2 \mathrm{~B}$ and $2 \mathrm{C}$, respectively), indicating the limited transport capacity of $\mathrm{Ca}$ following foliar application. For sweet cherry trees, a similar trend was observed, with the highest rate of ${ }^{45} \mathrm{Ca}$ distribution recorded when ${ }^{45} \mathrm{Ca}$ was supplied to the soil (Figure 2D). After root treatment, the highest ${ }^{45} \mathrm{Ca}$ amounts were measured in roots, followed by shoots, leaves, and trunk (Figure 2D). As for Chili pepper, when ${ }^{45} \mathrm{Ca}$ was applied to the apical or basal leaves (Figures 2E and 2F), over $90 \%$ of the supplied ${ }^{45} \mathrm{Ca}$ was found in the treated foliage. However, for this species, the rate of ${ }^{45} \mathrm{Ca}$ translocation from the treated leaves was significantly higher than for chilli pepper plants, leading to detectable ${ }^{45} \mathrm{Ca}$ increases in the trunk, shoot and basal leaves after ${ }^{45} \mathrm{Ca}$ supply to apical leaves (Figure 2E). Treatment of basal cherry tree leaves with ${ }^{45} \mathrm{Ca}$ also led to the translocation of a small amount of this Ca radiotracer to the trunk (Figure $2 \mathrm{~F}$ ).

Two months after the application of ${ }^{45} \mathrm{Ca}$ to the soil, chili pepper plants and sweet cherry trees absorbed approximately $8 \%$ and $2 \%$ of the $\mathrm{Ca}$, respectively. When analyzing the treated soil, about $70 \%$ and $30 \%$ of the applied ${ }^{45} \mathrm{Ca}$ was detected respectively in the top $0-5 \mathrm{~cm}$ and $5-10 \mathrm{~cm}$ soil layers where chili pepper plants were cultivated. In the case of sweet cherry trees, approximately $65 \%$ and $20 \%$ of the applied ${ }^{45} \mathrm{Ca}$ was found in the top $0-5 \mathrm{~cm}$ and $5-10$ $\mathrm{cm}$ soil layers, respectively. Hence, between species, significant differences on the recovery of root-applied ${ }^{45} \mathrm{Ca}$ were found for 5 to $10 \mathrm{~cm}$ soil depths, the lower values recorded for cherry trees suggesting a higher root activity of this species in this soil zone compared to chili pepper plants. At $10 \mathrm{~cm}$ soil depths and below, no detectable ${ }^{45} \mathrm{Ca}$ concentrations were measured (data not shown).

\section{Leaf anatomy}

Scanning electron micrographs show that the central vein of chili pepper leaves (Figure 3A) are more prominent and have smaller and more irregular vascular bundles, compared to cherry leaves (Figure 3C). Chili pepper leaves are thinner, have bigger epidermal cells, but a more irregular mesophyll structure (Figure 3B), compared to palisade and spongy parenchyma in cherry leaf (Figure 3D). Stomata were found only in the lower (abaxial) surface of cherry leaf (Figure 3G), while both leaf sides of Chili pepper had stomata, but densities 
were higher on the abaxial side (Table 1; Figure 3E). In addition, cherry leaves had smaller stomata (Table 1, Figure $3 \mathrm{H}$ ) compared to the abaxial side of chili pepper leaf (Figure 3F).

\section{Discussion}

In this study, the rate of $\mathrm{Ca}$ accumulation and distribution in chili pepper plants and sweet cherry trees was evaluated using ${ }^{45} \mathrm{Ca}$ as a tracer. The total plant biomass of approximately 4-month old chili pepper plants was lower than that of 2-year old cherry trees, mainly due to the absence of lignified, secondary tissues in pepper compared to woody species which develop secondary xylem and phloem (Sun et al., 2003). Shoots and roots of herbaceous plants differ from those of woody plants, for example, concerning their pattern of development, morphology, and functionality (e.g.,
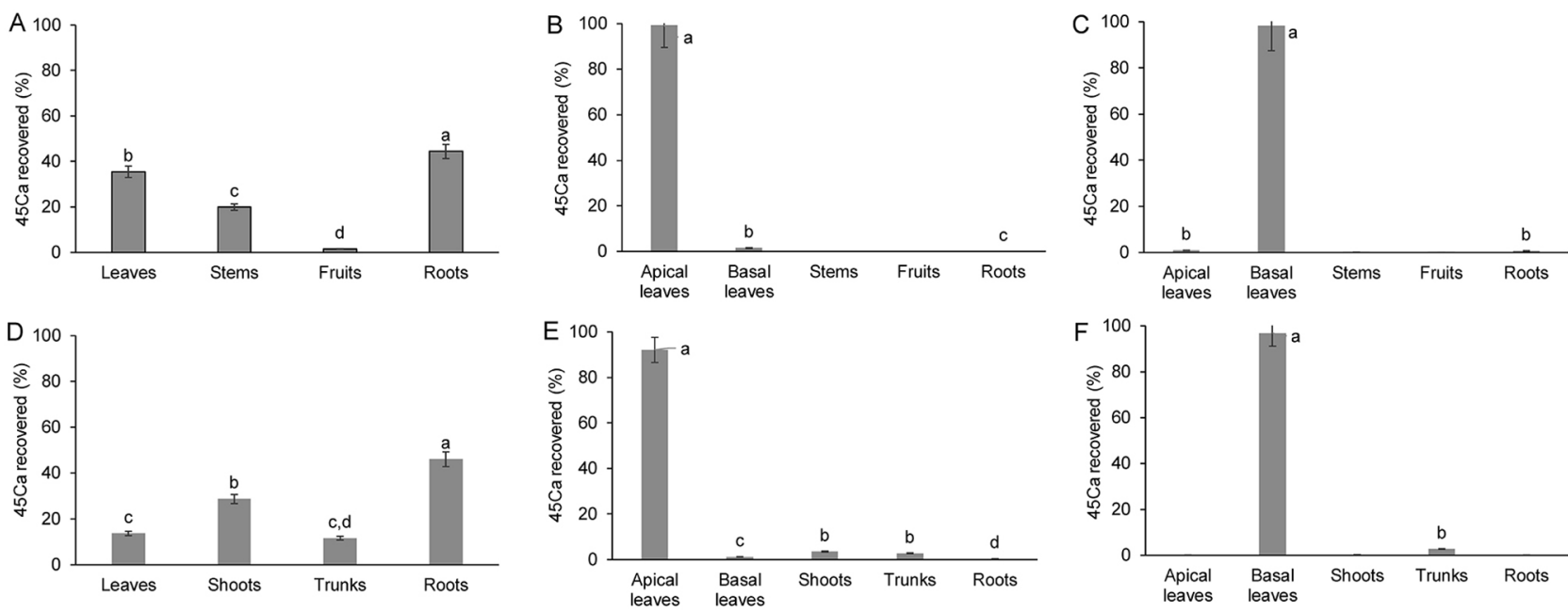

Figure 2 - Distribution of ${ }^{45} \mathrm{Ca}(\%)$ in different tissues of Chili pepper (A, B, C) and sweet cherry (D, E, F) plants. The recovery of ${ }^{45} \mathrm{Ca}$ in plant organs is shown following ${ }^{45} \mathrm{C}$ a soil application (A, C), ${ }^{45} \mathrm{Ca}$ supply to apical leaves (B, E) or ${ }^{45} \mathrm{Ca}$ supply to basal I leaves (C, F). Data are means $\pm S D(n=3)$. Different letters indicate different levels of significance according to the Tukey test $(p<0.05)$.
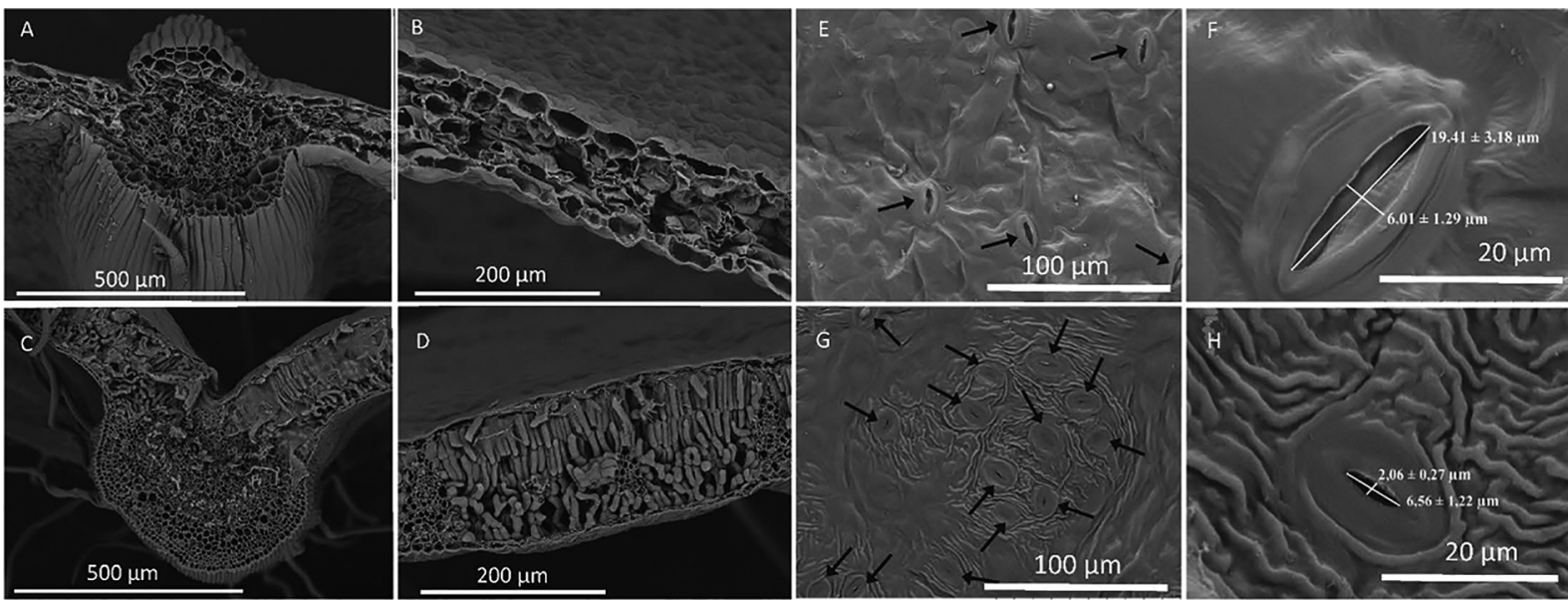

Figure 3 - Scanning electron micrographs of Chili pepper $(A, B, E, F)$ and cherry tree $(C, D, G, H)$ leaf parts. $(A, C)$ central veins, (B, D) leaf cross-sections, $(E, G)$ abaxial leaf side (stomata are indicated with arrows), and $(F, H)$ stomata.

Table 1 - Stomatal density and stomatal pore size of chili pepper and cherry tree leaves. Data are means \pm standard error $(n=15)$. Between species and for abaxial leaf sides, values marked with different letters are significantly different according to the Tukey test $(p<0.05)$.

\begin{tabular}{|c|c|c|c|c|c|c|}
\hline \multirow{2}{*}{ Species } & \multicolumn{2}{|c|}{ Stomatal density $\left(\mathrm{N}^{\circ} \mathrm{mm}^{-2}\right)$} & \multicolumn{2}{|c|}{ Pore length $(\mu \mathrm{m})$} & \multicolumn{2}{|c|}{ Pore width $(\mu \mathrm{m})$} \\
\hline & Adaxial & Abaxial & Adaxial & Abaxial & Adaxial & Abaxial \\
\hline Pepper & $62.7 \pm 3.1$ & $125.3 \pm 15.7 b$ & $12.4 \pm 0.6$ & $19.4 \pm 3.1 \mathrm{a}$ & $2.4 \pm 0.0$ & $6.0 \pm 1.2 a$ \\
\hline Cherry & - & $407.3 \pm 59.5 a$ & - & $6.5 \pm 1.2 b$ & - & $2.0 \pm 0.2 b$ \\
\hline
\end{tabular}


absorption and transport of water and nutrients; Shipley and $\mathrm{Vu}, 2002$; Sun et al., 2004). In chili pepper plants, the highest $\mathrm{Ca}$ content partitioning was associated with aerial parts (leaves plus stems), while roots had the greatest $\mathrm{Ca}$ contents in sweet cherry trees. This may be related to $\mathrm{Ca}^{+2}$ accumulation and relative immobilization in the trunk and bark (Federer et al., 1989; Turner and Lambert, 2005). In this study, leaf Ca concentration was about $1.5 \%$ for chili pepper plants and $2 \%$ for sweet cherry trees, which is within the Ca sufficiency range $(1.2-2.4 \%)$ described for these species (Reuter et al., 1997). Chili pepper had approximately $30 \%$ leaf biomass, while sweet cherry trees had a leaf biomass below $10 \%$, which may be associated with a trade-off between forming woody tissues or leaves in the woody species (Cornelissen et al., 1996). Similar root biomass partitioning values have been reported for cherry (Bonomelli and Artacho, 2013) and sweet orange trees (Mattos Jr. et al., 2003).

When analyzing the rate of ${ }^{45} \mathrm{Ca}$ transport and accumulation, both species showed certain similarities. In treatments where ${ }^{45} \mathrm{Ca}$ was applied to apical or basal leaves, ${ }^{45} \mathrm{Ca}$ was chiefly found in the treated foliage. However, when ${ }^{45} \mathrm{Ca}$ was applied to the soil, there was a higher rate of ${ }^{45} \mathrm{Ca}$ distribution within chilli pepper plants and cherry trees. The highest rate of delivery of root-applied ${ }^{45} \mathrm{Ca}$ is associated to xylem transport from roots to shoots, and the subsequent distribution to different aerial organs following the transpiration stream (Montanaro et al., 2014, 2015). Hence, the transport of $\mathrm{Ca}$ in the xylem can be considered the natural mechanisms of distribution of the element to aerial organs following root $\mathrm{Ca}$ absorption, which can also be limiting for the delivery of sufficient amounts of Ca to fruiting organs (Torres et al., 2017; Val et al., 2008). When ${ }^{45} \mathrm{Ca}$ was applied to the soil, it remained mostly in the upper $10 \mathrm{~cm}$ soil layer. Thus, root-applied Ca can be available to be absorbed in the top soil, where a high root activity may occur (Marschner, 2012; Riekerk, 1971), with some leaching risk. Due to the limited phloem mobility of $\mathrm{Ca}$, foliar Ca supply may be ineffective if absorption rates are low. Following foliar $\mathrm{Ca}$ application, most applied $\mathrm{Ca}$ may remain in the treated area. Additionally, after foliar/fruit surface $\mathrm{Ca}$ absorption of a Ca spray fertilizer, most exogenous $\mathrm{Ca}$, which may have penetrated thought the organ surface, may be accumulated in the external tissues, such as the leaf epidermis or fruit peel (Bonomelli and Ruiz, 2010; Kluge et al, 1999; Sampaio et al., 1999; Val et al., 2008). Thereby, direct treatment of low transpiring organs, like fruits with $\mathrm{Ca}$-containing solutions, may help increase $\mathrm{Ca}$ contents and avoid the development of Ca-related disorders (Khalaj et al., 2016). However, more research efforts are needed to optimize $\mathrm{Ca}$ fertilization, for instance, characterizing optimal fruit developmental stages and application timing of foliar and root $\mathrm{Ca}$ fertilizers, or improving $\mathrm{Ca}$ foliar fertilizer formulations.
Leaf structure and morphology may affect the absorption and distribution of foliar-applied nutrients (Fernández et al., 2017). The morphology of the central vein was different and in the case of chili pepper, it protruded from the adaxial and abaxial surface (Figure 3A) compared with the concave structure of the adaxial cherry leaf vein (Figure 3C). This may prevent the absorption of a foliar fertilizer solution through the veins of chili pepper leaf, in contrast to the potential accumulation of liquids in the concave veins of the upper cheery leaf side that may facilitate the absorption of foliar-applied $\mathrm{Ca}$, as reported by Bahamonde et al. (2018). Differences in stomatal density and pore size were observed for pepper versus cherry leaves, which may also affect the absorption process of foliar Ca sprays. Pepper leaf is amphistomatous (Weryszko-Chmielewska and Michalojc, 2009) and have larger pore sizes. On the other hand, cherry leaf is hypostomatous (Gonçalves et al., 2008) and have four times smaller stomata compared to pepper leaves. Assuming that the stomatal pathway is relevant for both species, foliar Ca applications should be applied preferably during the day when stomata are open and covering the abaxial side mainly in the case of cherry trees.

When considering root versus foliar Ca fertilization, both methods involve potential advantages and constraints related to limitations associated to $\mathrm{Ca}$ absorption and mobility. Furthermore, Ca fertilizer absorption and transport mechanisms in plants may vary to a certain extent between species, as shown in this investigation. Our experiments on ${ }^{45} \mathrm{Ca}$ mobility showed that the rate of Ca re-translocation after foliar application is low, but higher in cherry trees compared to chili pepper plants. Fruit Ca enrichment at early developmental stages via multiple Ca spray treatments may be a means to increase the concentration of the element and limit the occurrence of Ca-related disorders, as suggested by several authors (e.g., Correia et al., 2020; Torres et al., 2017; Val et al., 2008). However, further research should be carried out to assess, for example, the rate of foliar Ca permeability, potential role of the cuticle, stomata, trichomes, veins, and other potential surface features in the process of foliar absorption and effectiveness of different foliar spray formulations (Fernández and Bahamonde, 2020).

\section{Conclusion}

Soil application of ${ }^{45} \mathrm{CaCl}_{2}$ to chili pepper plants and sweet cherry trees led to the highest rate of $\mathrm{Ca}$ transport to aerial plant organs. For both species, ${ }^{45} \mathrm{CaCl}_{2}$ solution application to basal and apical leaves resulted into limited ${ }^{45} \mathrm{Ca}$ movement from the site of treatment to other tissues, but a higher mobility of foliar-applied ${ }^{45} \mathrm{Ca}$ was observed for cherry trees. Therefore, it is concluded that the most effective Ca fertilization means to increase fruit $\mathrm{Ca}$ concentrations may be direct treatment of developing fruiting organs with multiple $\mathrm{Ca}$ spray applications. However, differences in $\mathrm{Ca}$ absorption and 
translocation rates may be found, for example, between species, varieties, organ ontogeny or environmental conditions at the time of spray application. Furthermore, factors, such as Ca fertilizer formulation, technology of application, and timing should also be considered in future investigations to optimize the response of crop plants to Ca fertilization.

\section{Authors' Contributions}

Conceptualization: Bonomelli, C. Data acquisition: C; Alcalde, C.; Videla, X.; Rojas Silva, X. Data analysis: Bonomelli, C.; Aguilera, C; Alcalde, C. Writing and editing: Bonomelli, C.; Fernández, V.

\section{References}

Bahamonde, H.A.; Gil, L.; Fernández, V. 2018. Surface properties and permeability to calcium chloride of Fagus sylvatica and Quercus petraea leaves of different canopy heights. Frontiers in Plant Science 9: 494.

Bonomelli, C.; Ruiz, R. 2010. Effects of foliar and soil calcium application on yield and quality of table grape cv.'Thompson Seedless'. Journal of Plant Nutrition 33: 299-314.

Bonomelli, C.; Artacho, P. 2013. Nitrogen application to nonbearing 'Bing' sweet cherry trees on Gisela ${ }^{\circledR} 6$ rootstock: effects on accumulation and partitioning of biomass and nitrogen. Scientia Horticulturae 162: 293-304.

Busse, J.S.; Palta J.P. 2006. Investigating the in vivo calcium transport path to developing potato tuber using ${ }^{45} \mathrm{Ca}$ : a new concept in potato tuber calcium nutrition. Physiologia Plantarum 128: 313-23.

Cornelissen, J.H.C.; Diez, P.C.; Hunt, R. 1996. Seedling growth, allocation and leaf attributes in a wide range of woody plant species and types. Journal of Ecolology 84: 755-65.

Correia, S.; Queirós, F.; Ferreira, H.; Morais, M.C.; Afonso, S.; Silva, A.P.; Gonçalves, B. 2020. Foliar application of calcium and growth regulators modulate sweet cherry (Prunus avium L.) tree performance. Plants 9: 410.

Eichert, T.; Burkhardt, J. 2001. Quantification of stomatal uptake of ionic solutes using a new model system. Journal of Experimental Botany 52: 771-81.

Eichert, T.; Kurtz, A.; Steiner, U.; Goldbach, H.E. 2008. Size exclusion limits and lateral heterogeneity of the stomatal foliar uptake pathway for aqueous solutes and water suspended nanoparticles. Physiologia Plantarum 134: 151-160.

Fernández, V.; Bahamonde, H.A. 2020. Advances in foliar fertilizers to optimize crop nutrition. p. 1-26. In: Rengel, Z., ed. Achieving sustainable crop nutrition. Burleigh Dodds Science, Cambridge, UK.

Fernández, V.; Bahamonde, H.A.; Peguero-Pina, J.J.; Gil-Pelegrín, E.; Sancho-Knapik, D.; Gil, L.; Goldbach, H.E.; Eichert, T. 2017. Physico-chemical properties of plant cuticles and their functional and ecological significance. Journal of Experimental Botany 68: 5293-5306.

Fernández, V.; Brown, P.H. 2013. From plant surface to plant metabolism: the uncertain fate of foliar-applied nutrients. Frontiers in Plant Science 4: 289.
Fernández, V.; Sotiropoulos, T.; Brown P H. 2013. Foliar Fertilization: Scientific Principles and Field Practices. International Fertilizer Industry Association, Paris, France.

Fernández, V.; Eichert, T. 2009. Uptake of hydrophilic solutes through plant leaves: current state of knowledge and perspectives of foliar fertilization. Critical Reviews in Plant Sciences 28: 36-68.

Freitas, S.T.; Amarante, C.V.T.; Mitcham, E.J. 2015. Mechanisms regulating apple cultivar susceptibility to bitter pit. Scientia Horticulturae 186: 54-60.

Freitas, S.T.; Mitcham, E.J. 2012. Factors involved in fruit calcium deficiency disorders. Horticutural Reviews 40: 107-46.

Gomes, M.H.F.; Migliavacca, R.A.; Otto, R.; Carvalho, H.W.P.D. 2020. Physicochemical characterization of fertilizers containing concentrated suspensions of $\mathrm{CuO}, \mathrm{MnCO}_{3}$ and $\mathrm{ZnO}$. Scientia Agricola 77: e20180384.

Gonçalves, B.; Correia, C.M.; Silva, A.P.; Bacelar, E.A.; Santos, A.; Moutinho-Pereira, J.M. 2008. Leaf structure and function of sweet cherry tree (Prunus avium L.) cultivars with open and dense canopies. Scientia Horticulturae 116: 381-7.

Hocking, B.; Tyerman, S.D.; Burton, R.A.; Gilliham M. 2016. Fruit calcium: transport and physiology. Frontiers in Plant Science 7: 569 .

Khalaj, K., Ahmadi, N.; Souri, M.K. 2016. Improvement of postharvest quality of asian pear fruits by foliar application of boron and calcium. Horticulturae 3: 15.

Kluge, R.A.; Scarpare, F.J.; Sampaio, V. 1999. Ripening of 'Tommy Atkins' mangoes treated with $\mathrm{Ca}$ in pre-harvest. Scientia Agricola 56: 749-752 (in Portuguese, with abstract in English).

Marschner P, 2012. Mineral Nutrition of Higher Plants. 3ed. Academic Press, London, UK.

Mattos Jr., D.; Quaggio, J.A.; Cantarella, H.; Alva, A.K. 2003. Nutrient content of biomass components of Hamlin sweet orange trees. Scientia Agricola 60: 155-160.

Montanaro, G.; Dichiom B.; Lang, A.; Mininni, A.N.; Nuzzo, V.; Clearwater, M.J.; Xiloyannis, C. 2014. Internal versus external control of calcium nutrition in kiwifruit. Journal of Plant Nutritition and Soil Science 177: 819-830.

Montanaro, G.; Dichiom B.; Lang, A.; Mininnim A.N.; Xiloyannis, C. 2015. Fruit calcium accumulation coupled and uncoupled from its transpiration in kiwifruit. Journal of Plant Physiology 181: 67-74.

Reuter, D.J.; Robinson, J.B.; Dutkiewicz, C. 1997. Plant analysis : an interpretation manual. 2ed. CSIRO Publishing, Canberra, Australia.

Riekerk, H. 1971. The mobility of phosphorus, potassium, and calcium in a forest soil. Soil Science Society of America Journal 35: 350-6.

Sampaio, V.R.; Scarpare Filho, J.A.; Kluge, R.A. 1999. Physiological disorders in mango: effect of foliar sprays with calcium. Scientia Agricola 56: 459-463 (in Portuguese, with abstract in English).

Saure, M.C. 2005. Calcium translocation to fleshy fruit: its mechanism and endogenous control Scientia Horticulturae 105: 65-89

Shipley, B.; Vu, T.T. 2002. Dry matter content as a measure of dry matter concentration in plants and their parts. New Phytologist 153: 359-64. 
Song, W.; Yim, J.; Kurniadinata, O.F.; Wang, H.; Huang, X. 2018. Linking fruit $\mathrm{Ca}$ uptake capacity to fruit growth and pedicel anatomy, a cross-species study. Frontiers in Plant Science 9: 575.

Souri, M.K.; Hatamian, M. 2019. Aminochelates in plant nutrition; a review. Journal of Plant Nutrition 42: 67-78

Souri, M.K.; Sooraki, F.Y. 2019. Benefits of organic fertilizers spray on growth quality of chili pepper seedlings under cool temperature. Journal of Plant Nutrition 42: 650-656.

Sun, Q.; Yodam K.; Suzuki, H. 2004. Internal axial light conduction in the stems and roots of herbaceous plants. Journal of Experimental Botany 56:191-203.

Sun, Q.; Yoda, K.; Suzuki, M.; Suzuki, H. 2003. Vascular tissue in the stem and roots of woody plants can conduct light. Journal of Experimental Botany 54: 1627-35.

Torres, E.; Recasens, I.; Lordan, J.; Alegre, S. 2017. Combination of strategies to supply calcium and reduce bitter pit in 'Golden Delicious' apples. Scientia Horticulturae 217: 179-188.

Turner, J.; Lambert, M. 2005. Soil and nutrient processes related to eucalypt forest dieback. Australian Forestry 68: 251-6.
Val, J.; Monge, E.; Risco, D.; Blanco, A. 2008. Effect of pre-harvest calcium sprays on calcium concentrations in the skin and flesh of apples. Journal of Plant Nutrition 31: 1889-1905

Videla, X.; Rojas-Silva, X.; Nario, A.; Arias, M.I.; Bonomelli, C. 2019. Calcination method of $45 \mathrm{Ca}$ samples for isotope ratio analysis via liquid scintillation. Communications in Soil Science and Plant Analysis 50: 412-420.

Weryszko-Chmielewska, E.; Michalojc, Z. 2009. Anatomical features of leaves of sweet pepper (Capsicum annuum L.) fed with calcium using foliar nutrition. Acta Agrobotanica 62:155164.

White, P.J.; Broadley, M.R. 2003. Calcium in plants. Annals of Botany 92: 487-511. 